\title{
Status and Habitat Characteristics of Cypripedium kentuckiense (Kentucky lady's slipper) in Southeastern Oklahoma
}

\author{
Amy K. Buthod \\ Oklahoma Biological Survey \\ University of Oklahoma \\ Norman, OK 73019 \\ e-mail: amybuthod@ou.edu
}

\author{
B. W. Hoagland \\ Oklahoma Biological Survey and \\ Department of Geography \\ University of Oklahoma \\ Norman, OK 73019 \\ e-mail: bhoagland@ou.edu
}

Cypripedium kentuckiense is a long-lived herbaceous perennial that inhabits floodplain and mesic hardwood forests. It occurs in Alabama, Kentucky, Louisiana, Mississippi, Oklahoma, Tennessee, Texas, and Virginia and has been reported from Choctaw, LeFlore, McCurtain, and Pushmataha counties in Oklahoma. $C$. kentuckiense is considered a rare species throughout its range, but is not currently protected under the United States Endangered Species Act. The objectives of this study were to (1) determine whether known populations of $C$. kentuckiense were persisting in Oklahoma and (2) characterize habitat structure. Twelve sites were surveyed in 2001 and 2002 for populations of $C$. kentuckiense, but only three persistent populations were found. The populations that were relocated numbered fewer than 20 total stems and all showed a dramatic decline in population size relative to previous surveys.

\section{INTRODUCTION}

Cypripedium kentuckiense is a long-lived herbaceous perennial that inhabits floodplain or mesic hardwood forests or woodland springs and seeps (Case et al., 1998; Reed 1982, Hooks 2000, Magrath 2001). Populations of C. kentuckiense occur in Alabama, Kentucky, Louisiana, Mississippi, Oklahoma, Tennessee, Texas, and Virginia (Figure; USDA 2002). In Oklahoma, C. kentuckiense has been reported from

Choctaw, LeFlore, McCurtain, and Pushmataha counties (Hoagland et al. 2004). Over 156 populations are known to exist throughout its range, the majority of which occur in Arkansas. Oklahoma harbors only $4.5 \%$ of C. kentuckiense populations (Atwood 1984, 1985; Case et al. 1998). Population size averages less than 20 individuals (Weldy et al. 1996), though some in Arkansas exceed 800 individuals (Hooks 2000).

Cypripedium. kentuckiense is considered a rare species throughout its range, but is not currently protected under the U.S. Endangered Species Act. Prior to 1996, it was listed as a category 2 (C2) species by the
U.S. Fish and Wildlife Service. A C2 species is defined as "... a likely candidate for federal listing as endangered or threatened, but it is necessary to obtain further information regarding possible threats" (Department of the Interior 1993).

State and federal agencies evaluate the conservation status of a species using a two tiered, geographical approach developed by The Nature Conservancy (Groves et al. 1995). This system ranks species imperilment at the state $(\mathrm{S})$ and $\operatorname{global}(\mathrm{G})$ levels on a scale of 1-5; 1 representing a species that is imperiled and 5 , one that is demonstrably secure. NatureServe, a conservation information organization, has assigned C. kentuckiense a global rank of G3, indicating a species that is "... either very rare and local throughout its range or found locally (even abundantly at some of its locations) in a restricted range, or because of other factors making it vulnerable to extinction throughout its range..." (NatureServe 2004). The Oklahoma Natural Heritage Inventory (ONHI) has assigned $C$. kentuckiense a state rank of S1, indicating a 
species “...critically imperiled... because of extreme rarity (five or fewer occurrences or very few remaining individuals or acres) or because of some factor of its biology making it especially vulnerable to extinction" (ONHI 2001). In comparison, Arkansas and Kentucky rank C. kentuckiense as S3 (Arkansas Natural Heritage Commission 2001; Kentucky Nature Preserves Commissions 2001), Tennessee S1S2

(Tenessee Department of Environment and Conservation 2001, and Alabama Louisiana, Mississippi, and Virginia as S1 (Alabama
Natural Heritage Program 1996; Louisiana Natural Heritage Program 2002; Mississippi Museum of Natural History 2002; Virginia Natural Heritage Program 2002) by Heritage Programs in those states. An S-rank was not available for Texas (Texas Conservation Data Center 2001.

The objectives of this study were (1) to verify and determine whether known populations of $C$. kentuckiense persist in Oklahoma and (2) to gather quantitative habitat data.
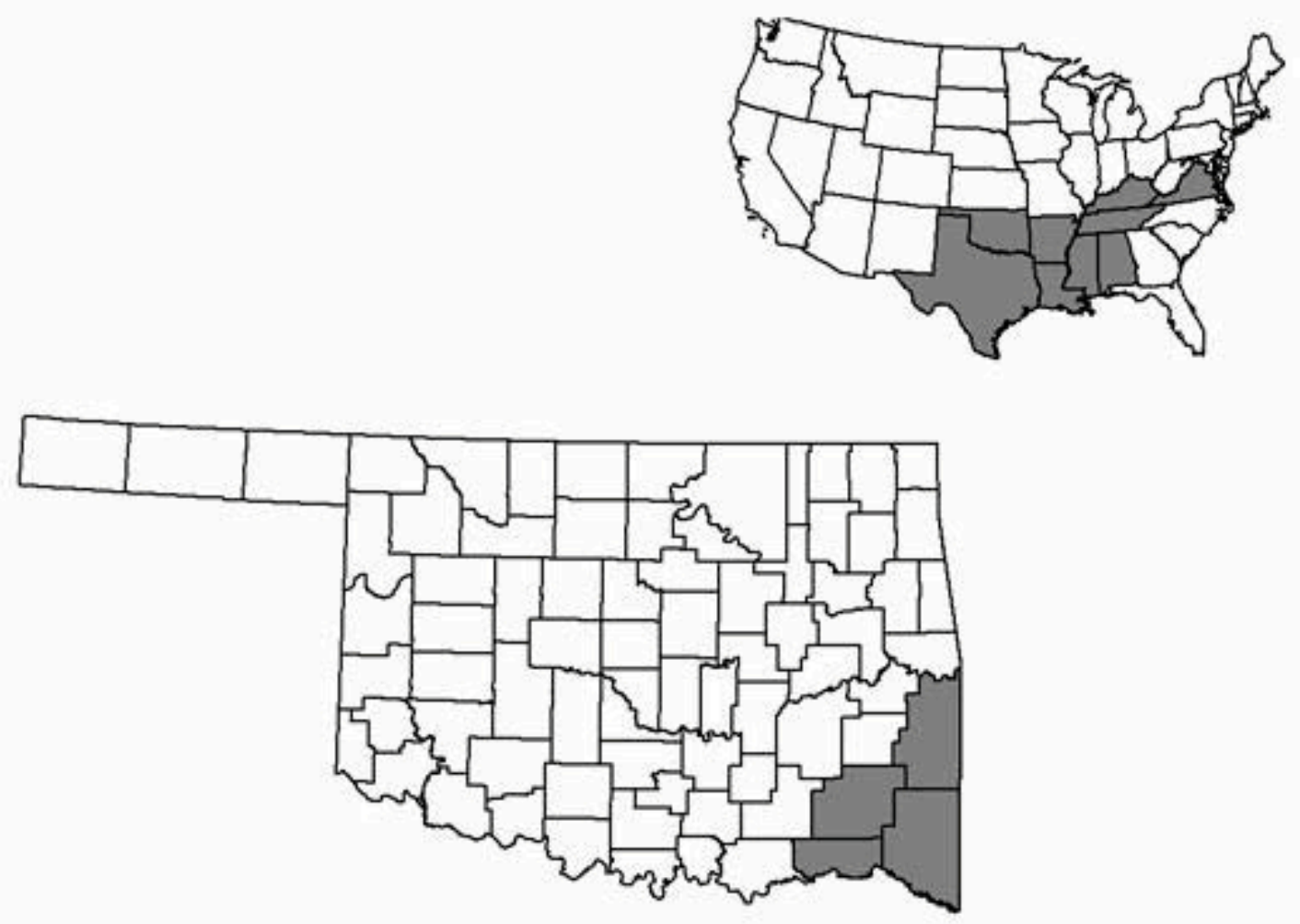

Figure National and state distribution of Cypripedium kentuckiense (Kentucky lady's slipper) (USDA 2002). 


\section{METHODS}

Sites visited in this study were obtained the ONHI, which maintains a spatial database of rare species locations. Each site was visited from late April to early May, the peak blooming period, in the springs of 2001 and 2002. All sites were thoroughly searched in an attempt to relocate previously documented $C$. kentuckiense populations. If a population was not found at a site, the absence was noted and no further data were collected. If a population was found, then several ecological variables were measured. These data were collected to quantitatively characterize the habitat of $C$. kentuckiense and provide information that can be utilized in future attempts to locate new populations.

Population and habitat data were collected from a quadrat encompassing all C. kentuckiense stems. The minimal quadrat size used was $1.0 \mathrm{~m}$ by $1.0 \mathrm{~m}$. If the population occupied a larger area, additional $1 \mathrm{~m}^{2}$ quadrats were added until the total population was within a sampling grid. Once the sampling grid was established, percent cover of $C$. kentuckiense was visually estimated in intervals of $5 \%$ and the number of stems counted. The numbers of flowering, fruiting (mature and immature), immature stems, and senescent stems were also recorded.

Habitat data consisted of biotic and abiotic factors. First, each species in the sampling grid was recorded. Two types of data were then collected for these associated species. First, percent cover was estimated for each understory species (including woody plants under $2 \mathrm{~cm}$ diameter) in increments of $5 \%$. If only a single stem of a species was present, it was given a value of $1 \%$. Second, the diameter-atbreast height $(\mathrm{DBH})$ was measured for all woody plants $>2 \mathrm{~cm}$ diameter. Basal area for canopy species was calculated following Wegner
(1984). Once these data were collected, a spherical densitometer was used to measure canopy closure. Soil depth was measured using an incremental probe. Finally, Universal Transmercator coordinates were recorded using a Garmin 3+ Global Positioning System (GPS) unit in order to resolve ambiguities in written location information. However, these data are not presented here because C. kentuckiense is a species of conservation concern.

\section{RESULTS AND DISCUSSION}

A total of twelve sites were surveyed in 2001 and 2002 for populations of $C$. kentuckiense; two in Choctaw County, six in LeFlore county, three in McCurtain County, and one in Pushmataha County. The persistence of three populations was verified. Five populations could not be revisited due to insufficient location information. Four populations had been destroyed by timber harvest or conversion to unsuitable habitat for C. kentuckiense. No new sites were located.

The first population was verified on 7 May 2001. Thirteen stems of C. Kentuckiense were counted, two of which were in flower. This population occurred in a mesic floodplain forest with 78\% canopy closure. There were 21 associated plant species present. The most abundant were Lindera benzoin (30\% cover), Thalictrum dascycarpum (15\%), Podophyllum peltatum (10\%), and Toxicodendron radicans $(10 \%)$ (Table 1$)$. The canopy was composed exclusively of Ilex opaca, a common bottomland species in southeast Oklahoma (Hoagland et al., 1996). The low diversity of woody plants over $2 \mathrm{~cm}$ DBH (Table 2) and relatively open canopy $(78 \%)$ indicate the second growth character of this forest. Soil depth was equivalent for all sites.

This population was first reported in 1982, at which time 35 stems were recorded,

Buthod, A.K. and Hoagland, B.W. 
but no observations were made regarding phenological state. The site was visited again in 1984 and 30 plants were recorded. Additional surveys were conducted in 1985 (23 plants located, two flowering), 1988 (13 plants; phenology not recorded), 1990 (less than 20 plants present, phenology not recorded), 1991 (21 plants, four in flower), 1993 (12 plants, two in flower), and 1996 (no plants located).

A second population was verified on 8 May 2001. Nine broadly dispersed stems of C. kentuckiense were present. Individuals in this population were widely dispersed. Eleven associated species were present, of which the most common were Parthenocissus quinquefolia (20\% cover), Panicum sp. (10\%), and Podophyllum peltatum (10\%) (See Table 1). The canopy was relatively dense $(87.3 \%)$ and consisted of eight species. The highest basal areas were recorded for Quercus shumardii and Carpinus caroliniana, both mesic species (Little 1981).

This population has been visited repeatedly since its discovery in 1988 (two plants, phenological stage not recorded), 1991 (nine plants flowering, two in fruit, and four sterile), 1992 (>10 plants with immature fruit), 1993 (11 plants, nine in flower), and 1996 (11 plants in vegetative condition).

A third population was verified on 8 May 2001. The population consisted of one flowering stem growing on a forested floodplain. Population and associated species data were collected from the $1.0 \mathrm{~m}^{2}$ plot. There were 21 associated plant species at this site (See Table 1). The most abundant were Panicum sp. (25\% cover), Parthenocissus quinquefolia (5\%), and Arisaema dracontium $(5 \%)$. Although the canopy density is highest for this plot, there were no canopy trees within the sample plot, therefore no basal area value could be calculated.
Previous surveys of the site were conducted in 1993 (one flowering stem recorded) and 1996 (one vegetative stem recorded).

Because of the limited number of sites sampled, a quantitative analysis of habitat structure is not possible.

\section{CONCLUSIONS}

Based upon this research, we conclude C. kentuckiense in Oklahoma is in jeopardy. Magrath (2001) had also stated that $C$. kentuckiense populations were in decline in Oklahoma. The populations that were relocated numbered fewer than 20 total stems and all showed a dramatic decline in population size relative to previous surveys. The primary threats to C. kentuckiense in Oklahoma are anthropogenic. Most populations of $C$. kentuckiense are located in areas of active timber harvesting, which present both direct and indirect threats. The most likely direct threat is destruction of a population by timber harvesting equipment. Indirect threats include road construction and structural alteration of adjacent forest stands. These reduce forest canopy cover, thus increasing the amount of light reaching the forest floor and allowing the introduction of invasive species. Since $C$. kentuckiense is difficult to propagate, it is frequently collected in the wild for the nursery trade. The construction of logging roads increases access to collectors. In addition, road construction itself can result in the destruction of a population.

Indirect threats to small, isolated populations included reduced genetic variability compared to large, contiguous populations, and the inability of pollinators to locate widely dispersed populations or those on the edge of a species range. In this regard, it is noteworthy that very few mature fruits or seedlings were documented in the populations reported here.

Nevertheless, additional populations of 
C. kentuckiense may be found in Oklahoma, with efforts focused on the Oachita National Forest (ONF) in LeFlore and McCurtain Counties. In Arkansas several new populations have been found on the ONF. Some populations consisted of 100 individuals or more (Hooks 2000). Populations located on the ONF are afforded a higher degree of protection and monitoring than those on private land. In addition, seep, spring, and riparian habitats are protected from timber extraction on Forest Service land. Thus, further exploration for populations of $C$. kentuckiense within Oklahoma is recommended. Likewise, sites known to have harbored populations of $C$. kentuckiense should be verified regularly.

\section{ACKNOWLEDGMENTS}

This project was funded by a grant from the United States Fish and Wildlife Service. We thank Newell McCarty for assistance in the field in 2001.

\section{LITERATURE CITED}

Alabama Natural Heritage Program. 1996. Plants list (on line). Available at: www.natureserve.org/nhp/us/al/pl ants.html. (Accessed 1 March 2004)

Arkansas Natural Heritage Commission. 2001. Plants of special concern (online). Available at: www.naturalheritage.org/ publications/rare. (Accessed 1 March2004).

Atwood, John T. 1984. In defense of Cypripedium kentuckiense C. F. Reed. American Orchid Society Bulletin 53(8): 835-841.

Atwood, John T. The range of Cypripedium kentuckiense. American Orchid Society Bulletin 54(10): 1197-1199.
Case, Martha A., Henry T. Mlodozeniec, Lisa E. Wallace, and Troy W. Weldy. 1998. Conservation genetics and taxonomic status of the rare Kentucky lady's slipper: Cypripedium kentuckiense (Orchidaceae). American Journal of Botany 85(12): 1779-1786.

Department of the Interior. 1993. Federal Register, Part IV 58(188): 51160.

Groves, C.R., M.L. Klein, and T.F. Breden. 1995. Natural Heritage Programs: public-private partnerships for biodiversity conservation. Wildlife Society Bulletin 23:784-790.

Hoagland, B.W., L.R. Sorrels and S.M. Glenn. 1996. Woody species composition of floodplain forests of the Little River, McCurtain and LeFlore Counties, Oklahoma. Proceedings of the Oklahoma Academy of Science 76:23-26.

Hoagland B.W., A.K. Buthod, I.H. Butler, P.H.C. Crawford, A.H. Udasi, W.J. Elisens, and R.J. Tyrl 2004. Oklahoma Vascular Plants Database (on line). Oklahoma Biological Survey, University of Oklahoma, Norman. Available at: www.biosurvey.ou.edu. (accessed 1 March 2004).

Hooks, Susan. 2000. Conservation Assessment for Cypripedium kentuckiense Reed on the Ouachita and Ozark St. Francis National Forests. United States Forest Service, Hot Springs, Arkansas.

Kentucky State Nature Preserves Commission. 2001. Endangered, threatened, special concern, and historic plants and animals of Kentucky (on line). Available at: www.kynaturepreserves.org/reports .html. (Accessed 1 March 2004).

Little, E.L. 1981. Forest trees of Oklahoma. Oklahoma Forestry Division, Publication number 1, Oklahoma City.

Buthod, A.K. and Hoagland, B.W. 
Louisiana Natural Heritage Programs. 2002. Rare plant species of Louisiana (on line). Available at: www.wlf.state.la.us. (Accessed 1 March 2004).

Magrath, L.K. 2001. Native Orchids of Oklahoma. Oklahoma Native Plant Record 1 (1):39-66.

Mississippi Museum of Natural Science. 2002. Natural heritage inventory plant database (on line). Available at: www.mdwfp.com/ museum $/ \mathrm{html} /$ research/plant db.a sp. (Accessed 1 March 2002).

NatureServe. 2004. NatureServe Explorer: An online encyclopedia of life (on line). Available at: www.natureserve.org/explorer. (Accessed 1 March 2004)

Oklahoma Natural Heritage Inventory. 2001. ONHI guide to status and rarity ranking codes (on line). Available at: www. biosurvey.ou.edu/heritage/publicat. html. (Accessed 1 March 2004).

Oklahoma Natural Heritage Inventory. 2001. ONHI working list of rare Oklahoma plants (on line). Available at: www.biosurvey.ou.edu/heritage/ publicat.html. (Accessed 1 March 2004).

Reed, Clyde F. 1982. Cypripedium kentuckiense Reed, a new species of orchid in Kentucky. Phytologia 50(4): 286-288.
Tennessee Department of Environment and Conservation. 2001. Rare and endangered plant list of Tennessee (on line). Available at: www.state.tn.us/environment/natur al.htm. (Accessed 1 March 2004).

Texas Conservation Data Center. 2001. Plant tracking list (on line). Available at:

nature.org/wherewework/northam erica/states/ texas/science/art6069.html. (Accessed 1 March 2004).

USDA, NRCS. 2002. The PLANTS database, version 3.5 (on line). Available at: http://plants.usda.gov/. National Plant Data Center, Baton Rouge, Louisiana. (Accessed 1 March 2004).

Virginia Natural Heritage Program. 2002. Rare plants (on line). Available at: www.dcr.state.va.us/dnh/nhrinfo.ht m (Accessed 1 March 2002).

Weldy, Troy W., Henry T. Mlodozeniec, Lisa E. Wallace, and Martha A. Case. 1996. The current status of Cypripedium kentuckiense (Orchidaceae) including a morphological analysis of a newly discovered population in eastern Virginia. Sida 17(2): 423-435.

Wenger, K.F. 1984. Forestry handbook. John Wiley and Son, New York 
Table 1 Percent cover data for associated herbaceous species and woody species $<2 \mathrm{~cm} \mathrm{DBH}$ at Cypripedium kentuckense sites in southeastern Oklahoma.

\begin{tabular}{|c|c|c|c|c|c|c|c|}
\hline & Site 1 & 2 & 3 & Site & 1 & 2 & 3 \\
\hline Acer rubrum & 1 & 0 & 1 & Podophyllum peltatum & 10 & 0 & 10 \\
\hline Allium canadense & 0 & 0 & 1 & Polystichum acrostichoides & 5 & 0 & 5 \\
\hline Arisaema dracontium & 0 & 5 & 0 & Potentilla spp. & 1 & 0 & 0 \\
\hline Campsis radicans & 1 & 0 & 0 & Prunus spp. & 1 & 0 & 0 \\
\hline Carex spp. & 1 & 1 & 0 & Ribes sp. & 0 & 1 & 0 \\
\hline Cercis canadensis & 0 & 0 & 1 & Quercus alba & 0 & 0 & 5 \\
\hline Cypripedium kentuckense & 5 & 5 & 1 & Salvia lyrata & 0 & 1 & 0 \\
\hline Euonymous americanus & 1 & 0 & 0 & Sassafras albidum & 1 & 0 & 0 \\
\hline Galium sp. & 1 & 0 & 0 & Senecio sp. & 0 & 5 & 1 \\
\hline Ilex opaca & 1 & 0 & 0 & Smilicina racemosa & 0 & 0 & 1 \\
\hline Impatiens capensis & 0 & 0 & 1 & Smilax glauca & 1 & 0 & 5 \\
\hline Krigia sp. & 0 & 1 & 0 & Thalictrum arkansanum & 0 & 1 & 0 \\
\hline Lindernia benzoin & 30 & 0 & 0 & Thalictrum dasycarpum & 15 & 0 & 5 \\
\hline Lysimachia quadrifolia & 0 & 0 & 5 & Toxicodendron radicans & 10 & 1 & 10 \\
\hline Mitchella repens & 1 & 0 & 0 & Ulmus alata & 0 & 0 & 1 \\
\hline Monarda virgatum & 0 & 0 & 1 & Viburnum rufidulum & 1 & 0 & 1 \\
\hline Ostrya virginiana & 1 & 0 & 1 & Viola sp. & 1 & 0 & 0 \\
\hline Oxalis violacea & 0 & 1 & 0 & Viola pedata & 1 & 0 & 1 \\
\hline Panicum spp. & 0 & 25 & 10 & Totals & 91 & 52 & 88 \\
\hline Parthenocissus quinquefolia & 1 & 5 & 20 & Overstory canopy $\%$ coverage & 78 & 87.5 & 93.8 \\
\hline Phacelia sp. & 0 & 0 & 1 & Soil depth (cm) & 30 & 30 & 30 \\
\hline
\end{tabular}

Buthod, A.K. and Hoagland, B.W. 
Table 2 Basal area $\left(\mathrm{cm}^{2} / \mathrm{m}^{2}\right)$ for woody species found in Cypridedium kentuckense. No woody plants occurred in the plot at site 3

\begin{tabular}{lcclcc}
\hline & Site & 1 & 2 & & Site 1 \\
\hline Alnus serrulata & 0 & 0.07 & Ilex opaca & 8.56 & 0 \\
Carpinus caroliniana & 0 & 8.0 & Liquidambar styraciflua & 0 & 8.0 \\
Cornus florida & 0 & 2.8 & Ostrya virginiana & 0 & 6.6 \\
Fraxinus pensylvanica & 0 & 0.29 & Quercus shumardii & 0 & 10.8
\end{tabular}

Buthod, A.K. and Hoagland, B.W. 